\title{
Determinants of Euro against US Dollar Rate of Exchange (USD/EUR) in the Long Run
}

\author{
Sławomir I. Bukowski ${ }^{1}$, Joanna E. Bukowska ${ }^{2}$
}

\begin{abstract}
:
The paper is a result of research which aimed to identify the factors determining the USD/EUR rate of exchange and the strength of the influence in the long run. In the research we used the Frenkel - Bilson model and an econometric model built on its basis.

In the research we formulated a hypothesis that the USD/EUR rate of exchange is determined in an economic and statistically significant way by the following factors: MI and M2 money supply in the euro area and USA, changes in the GDP rate of growth in the euro area and USA, changes in long term treasury bond yield to maturity in the euro area and USA. The results of the research confirmed the above hypothesis.
\end{abstract}

Key Words: theories of exchange rate, asset theories, Frenkel-Bilson model, long run determinants of exchange rate, cointegration of time series.

JEL code: F31.

\footnotetext{
${ }^{1}$ Full Professor, Dr Habil. Kazimierz Pulaski University of Technology and Humanities in Radom, Faculty of Economics, Department of International Business \& Finance. S.bukowski@wp.pl, mobile: +48604907040

${ }^{2}$ Assistant Professor, Ph.D., Kazimierz Pulaski University of Technology and Humanities in Radom, Faculty of Economics, Department of Economic Policy \& Banking
} 


\section{Introduction}

The goal of the research, the outcomes of which are presented here, was to identify the factors which determine the USD/EUR exchange rate and define how strong their influence on the USD/EUR exchange rate is (the euro price of a U.S. dollar) in the long run (an attempt at verifying the Frenkel-Bilson model).

The following research hypothesis was put forward:

The following factors influence the euro exchange rate economically and in a statistically significant way:

- changes in M1 and M2 money supplies in the euro area and USA,

- changes in the GDP growth rate in the euro area and USA,

- changes in long term treasury bonds' yield to maturity (YTM) in the euro area and USA.

The theoretical basis of our investigations was the Frenkel - Bilson monetary exchange rate model. It was used to construct an econometric model. The analysis of the model helped us verify the research hypothesis.

\section{Asset approach theories of exchange rate - literature review}

Among the theoretical approaches describing exchange rate changes in the shortand long run are asset theories (see: Figure 1). First of all they refer to the evolution of assets and their influence on the exchange rate. In these theories exchange rate is treated as the price of an asset and not as the price developing under the influence of the market (Bilski 2006, pp.76-79). The asset theories assume perfect capital mobility, rational expectations, perfect substitutability of assets, existence of covered interest rate parity and the financial market efficiency (Chrabonszczewska, Kalicki 1996, pp.41-42).

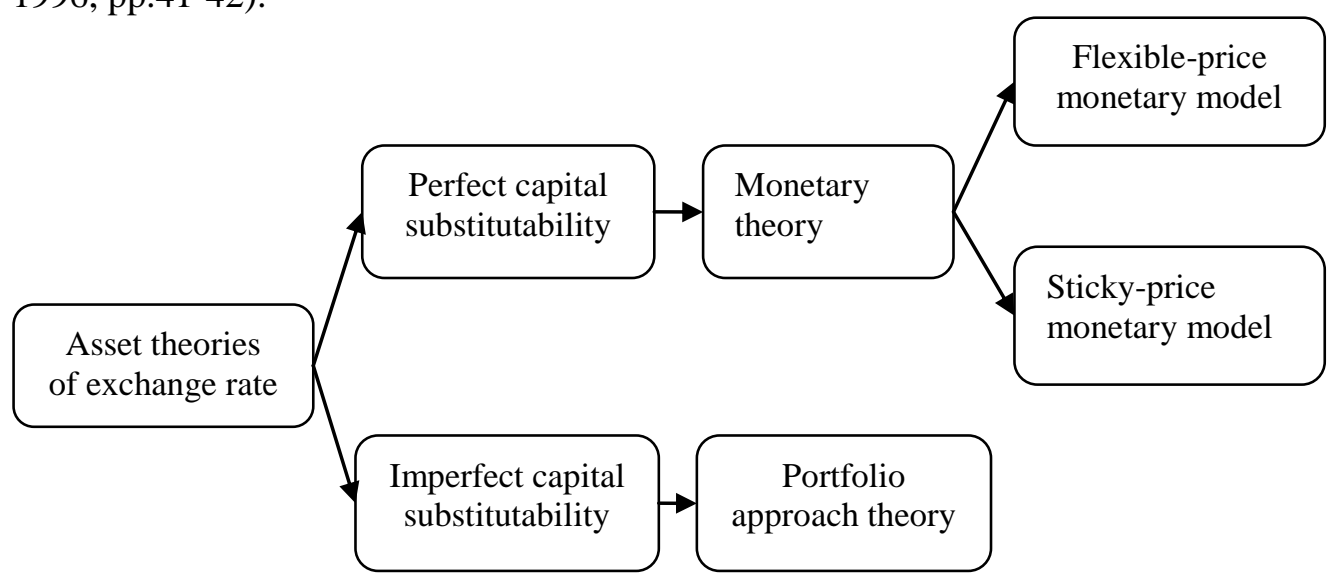

Figure 1. Diagram of asset theories

Source: authors' own compilation. 
Two asset theories are distinguished, i.e.: the portfolio approach and monetary approach. The basic difference between these two theories lies in capital substitutability. The former (portfolio) approach assumes imperfect substitutability of assets at international level, whereas the latter (monetary one) implies their perfect substitutability (Melvin 1992, p.157).

The first approach mentioned among resource-based theories of the exchange rate is the portfolio balance theory described also as the financial market theory. One of the founders of this theory is, among others, W. H. Branson (Branson 1977, pp.69-89).

The portfolio approach assumes that capital mobility is accompanied by imperfect capital substitutability understood as a choice between domestic and foreign assets and the risk premium. This theory explains short-term exchange rate changes in the context of price changes of one of the portfolio components, the said portfolio consisting of money and domestic and foreign financial assets. The value of the individual portfolio components depends on differences in expected yields on domestic and foreign assets and the risk related to them. On the other hand, changes in the structure of demand and supply in favour of any of the components result in exchange rate changes. For this reason, in the portfolio approach the exchange rate is defined as the relative price of resources of domestic and foreign assets. It can be written down as follows:

$$
e=\frac{B_{K}+M}{F_{K}} \varphi\left[i-i^{s}-E(d e / e)\right]
$$

where:

$e$ - exchange rate,

$M-$ money,

$B_{K}$ - domestic financial assets in the possession of domestic entities,

$F_{K}$ - foreign financial assets in the possession of domestic entities,

$\varphi$ - function of portfolio component supply,

$i-i^{\prime}$ - difference in interest rates at home and abroad,

$E^{d e / e-e x p e c t e d ~ e x c h a n g e ~ r a t e ~ c h a n g e . ~}$

In model approach, dependence of the exchange rate on the equilibrium of the markets of individual portfolio components is described in a direct way. Increased supply of foreign assets in the domestic market in terms of domestic currency causes exchange rate appreciation. Increased value of the exchange rate translates into decrease of the real value of foreign assets and, consequently, decreases their share in the portfolio composition and depreciation of the exchange rate. At the same time changes in differences between interest rates at home and abroad follow. The increased domestic interest rate leads to depreciation of the exchange rate, whereas increased foreign interest rates lead to its appreciation. Eventually, the values of resource demand and supply equalize and the market regains equilibrium 
(Chrabonszczewska, Kalicki 1996; Thalassinos et al., 2014; Thalassinos et al., 2015).

Monetary theory represents the second approach among asset theories. It assumes perfect capital substitutability and mobility, and lack of the risk premium. The essence of the monetary approach refers to the role of money in the structure of assets of economic entities which, according to the representatives of this theory, determines the exchange rate level. With these assumptions, the monetary theory postulates that the financial asset market does not play an important role in affecting the exchange rate. Contrary to the portfolio balance theory, the monetary theory claims that there is perfect substitutability of domestic and foreign assets, which mitigates deviations between the expected domestic and foreign yields. In monetary theories the main determinant affecting the exchange rate is money. Monetary theories try to explain the exchange rate changeability by analysing fluctuations in money demand and supply where changes in expectations are crucial, which apparently are affected by monetary factors. It is possible to distinguish two variants of monetary theories. The first one is the flexible-price monetary model (FPMM). It has its origins in the Chicago school and its authors include J. Bilson and J. Frenkel (Frankel 1976, pp.200-224; Bilson 1978, pp.392-397). The other variant of monetary theory is the sticky-price monetary model (SPMM), which originated in the Keynesian school. Adherents of this theory include, among others, R. Dornbusch, M. Fleming and, R. Mundell (Dornbosch 1976, pp.29-48; Fleming 1962, pp.369380; Mundell 1963, pp.475-485). Both models - the FPMM and SPMM, assume existence of purchasing power parity. Yet, in the FPMM, purchasing power parity occurs at any time, whereas in the case of the SPMM it is assumed that purchasing power parity is a long-term phenomenon with a possibility of short-term deviations from the equilibrium.

In the FPMM, purchasing power parity is believed to occur in both short- and longterm. It is also assumed that the equilibrium in the commodity market is maintained owing to perfectly flexible prices, whereas in the labour market - owing to perfectly flexible wages. On the other hand, exchange rates fully adjust to the equilibrium of currency demand and supply in the currency market.

In the FPMM, the equilibrium in the domestic and foreign market of money can be presented in the following way:

$$
\begin{aligned}
& m^{s}-p=\kappa y-\lambda i \\
& m^{s *}-p^{*}=\kappa^{*} y^{*}-\lambda^{*} i^{*}
\end{aligned}
$$

where:

$m^{s}$ - nominal money supply at home,

$p$-consumer price index, at home

$y$-real income at home, 
$i-$ nominal interest rate at home,

$\kappa, \lambda$-model parameters.

Symbol “*”indicates a respective variable and parameter for abroad.

All variables, except interest rates, are defined as natural logarithms.

Equations (2) and (3) indicate that in the case of both, domestic and foreign economy, the real demand for money is directly proportional to national income ${ }^{3}$ and inversely proportional to the interest rate in a given country ${ }^{4}$.

In the FPMM variant of monetary theories, the purchasing power parity condition which determines equilibrium in the commodity market can be represented by this equation:

$$
\bar{s}=p-p^{*}
$$

where:

$\bar{s}$ - nominal exchange rate of the equilibrium in terms of PPP (purchasing power parity).

After considering the equilibrium condition in the domestic and foreign money markets and assuming that model parameters equal $k=k^{*}$ and $\lambda=\lambda^{*}$ we obtain an equation which describes the exchange rate model according to monetary theories in the situation of flexible prices. Following substitution we obtain:

$$
\bar{s}=\left(m^{s}-m^{s *}\right)-\kappa\left(y-y^{*}\right)+\lambda\left(i-i^{*}\right)
$$

In accordance with the above equation, an increase (decline) in money supply at home in relation to the rigid demand for money determined by national income and interest rates causes an increase (decline) in prices and depreciation (appreciation) of the exchange rate. This means that an appropriate monetary authority can have an impact on domestic currency strengthening or weakening by limiting or increasing money supply.

To extend the monetary model in the situation of flexible prices means to include the exchange rate expectations in it. It can be represented by the following formula:

$$
E(\dot{s})=i-i^{*}
$$

where:

\footnotetext{
${ }^{3}$ There is demand for transactional money.

${ }^{4}$ The higher the interest rate is, the lower the demand for cash and the higher the demand for financial assets is.
} 
$E(s)$ - expected growth rate of the nominal exchange rate.

The equation defines the condition of the financial market equilibrium.

Using the basic equation of the monetary model in the situation of flexible prices (5) and substituting the difference between interest rates and home and abroad $(i-i *)$ with the expected growth rate of nominal exchange rate $(E(S))$ we obtain a model including expectations, which reads as follows:

$$
\bar{s}=\left(m^{s}-m^{s *}\right)-\kappa\left(y-y^{*}\right)+\lambda E(\dot{s})
$$

Extending the model and including the exchange rate expectations in it enables presentation of short-term dynamics of the exchange rate (Wdowiński 2010; Thalassinos and Politis 2012).

\section{Data and model}

In the years 2001-2008 the USD/EUR exchange rate was subject to appreciation. Between 2008-2013 the Euro became depreciated in relation to the US dollar, however, the scale of this depreciation was rather small when compared to appreciation of the Euro in the years 2001-2008 (See: Fig. 2).

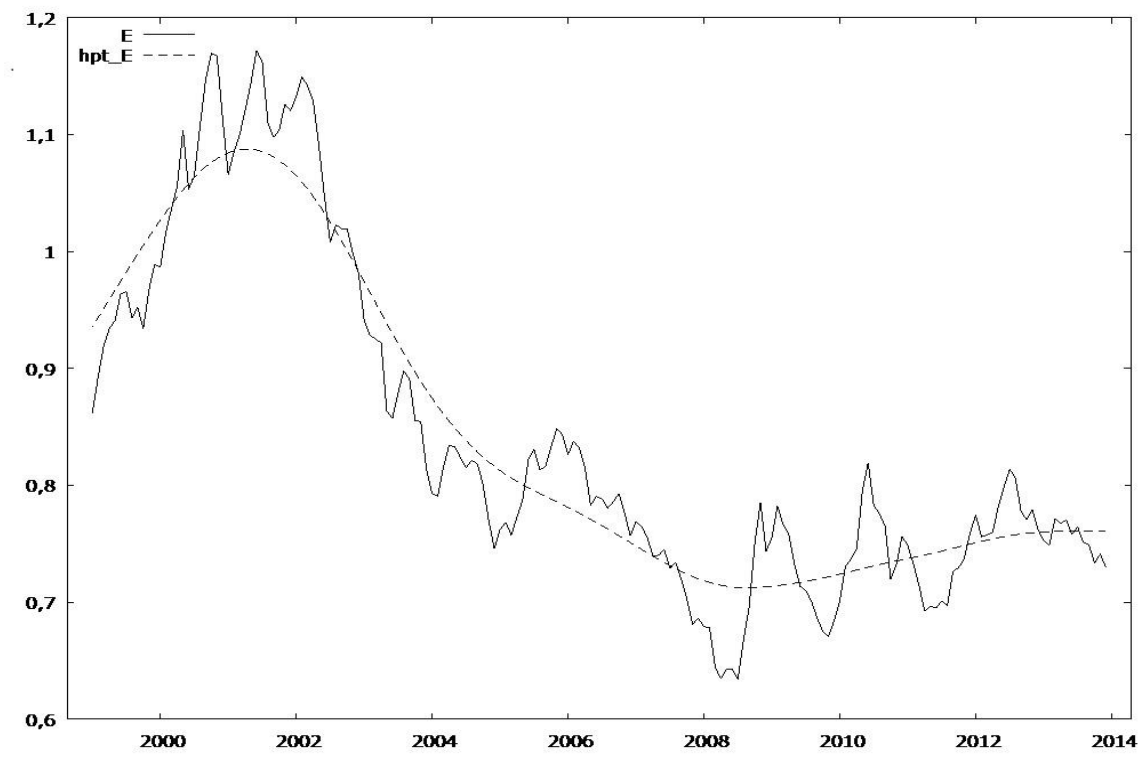

Figure 2. Nominal USD/EUR exchange rate, and smoothed by means of the Hodrick-Prescott filter $(\lambda=1400) \mathrm{E}$ - original , hpt_E - smoothing Source: authors' own compilation.

In order to test whether changes in monetary policy in the euro-area can stimulate the exchange rate changes in the long-run, an econometric model was built. The 
influences of changes in money supply, long-term interest rates, national income on the USD/EUR exchange rate were investigated. Specification of equations was based on the J. Frenkel - J. Bilson model. The theoretical Frenkel - Bilson model is represented by the formula which looks as follows:

$$
\bar{s}=\left(m^{s}-m^{s *}\right)-\kappa\left(y-y^{*}\right)+\lambda\left(i-i^{*}\right)
$$

In our research we used the monthly data from the period 1999-2013. The data regarding the USD/EUR exchange rate and a narrow money aggregate (M1) in the euro-area were taken from the ECB Statistical Data Warehouse. The data concerning the narrow money aggregate (M1) in the United States come from the database of Federal Reserve Statistical Releases. On the other hand, the data regarding long-term interest rates and GDP at constant prices are from the OECD database. In the research we also used annual data for the period 1999-2013 referring to GDP at constant prices, which for the purposes of the model were disaggregated.

The data regarding constant price GDP come for the IMF database (World Economic Outlook Database).

Additionally, in the model we adopted long term (10 year) treasury bond yield to maturity (YTM) in the euro area and USA as a proxy of long-term inflationary expectations.

On the basis of the above mentioned we formulated an equation which was GARCH estimated. The equation looked as follows:

$$
\begin{aligned}
& \Delta \ln E_{t}=a_{0}+a_{1} \Delta \ln M e 1_{t}+a_{2} \Delta \ln M u 1_{t}+a_{3} \Delta \ln Y e u r_{t}+a_{4} \Delta \ln Y e u r_{t-1}+ \\
& a_{5} \Delta \ln Y u s_{t}+a_{6} \Delta \ln Y u s_{t-1}+a_{7} \Delta I_{e, t}+a_{8} \Delta I_{e, t-1}+a_{9} \Delta I_{u, t}+a_{10} \Delta I_{u, t-1}+ \\
& a_{11} \Delta \ln E_{t-1}+a_{12} t+\xi_{t}
\end{aligned}
$$

where:

$\Delta \ln E$ - increments of the logarithm of the nominal USD/EUR exchange rate, $\Delta \operatorname{lnMe} 1$ - increments of the logarithm of monetary aggregate (M1) in the euro area, $\Delta \ln M u 1$ - increments of the logarithm of monetary aggregate (M1) in the United States,

$\Delta l n Y$ eur- increments of the logarithms of constant price GDP in the euro area, $\Delta l n Y$ us - increments of the logarithms of constant price GDP in the United States, $\Delta I_{e_{t}, t}, \Delta I_{u_{s}, t}$ - first differences in the long-term (10-year) treasury bond yield to maturity difference in the euro area and the USA

$a$ - absolute term,

$\xi$ - residual,

$t$ - time variable. 
The above equation explains evolution of the nominal USD/EUR exchange rate depending on 9 variables: the value of money aggregate (M1) in the euro area, the value of money aggregate (M1) in the United States, constant price GDP values in the euro area, constant price GDP in the euro area lagged by 1 month, constant price GDP values in the United States, constant price GDP values in the United States lagged by one month, the difference between long-term (10-year) treasury bond yield to maturity in the euro area and the United States, the difference in long-term (10-year) treasury bond yield to maturity between the euro area and the United States lagged by one month and the value of the nominal USD/EUR exchange rate lagged by one month.

The GARCH model was used for the model estimation. To eliminate a possibility of apparent regression, the Engle - Granger co-integration test was also carried out.

Table 1. GARCH estimation, observations used 1999:03-2013:12 ( $\mathrm{N}=178)$, dependent variable (Y): ld_E

Standard errors based on the Hessian matrix

\begin{tabular}{|c|c|c|c|c|c|}
\hline & Coefficient & Standard error & $z$ & $p$ value & \\
\hline const & -0.00411918 & 0.00462088 & -0.8914 & 0.37270 & \\
\hline ld_Me1 & 0.396927 & 0.226405 & 1.7532 & 0.07957 & $*$ \\
\hline ld_Mu1 & -0.316932 & 0.186617 & -1.6983 & 0.08945 & $*$ \\
\hline ld_Yeur & -0.999267 & 0.657368 & -1.5201 & 0.12849 & \\
\hline ld_Yeur_1 & 0.513382 & 0.65009 & 0.7897 & 0.42970 & \\
\hline ld_Yus & 0.26222 & 0.689321 & 0.3804 & 0.70365 & \\
\hline ld_Yus_1 & 0.112714 & 0.64747 & 0.1741 & 0.86180 & \\
\hline d_Ie & 0.368923 & 1.15954 & 0.3182 & 0.75036 & \\
\hline _Ie_1 & 1.55431 & 1.19013 & 1.3060 & 0.19155 & \\
\hline d_Iu & 1.43402 & 1.04252 & 1.3755 & 0.16897 & \\
\hline d_Iu_1 & -2.49559 & 1.00332 & -2.4873 & 0.01287 & $* *$ \\
\hline time & $1.88191 \mathrm{e}-05$ & $3.67794 \mathrm{e}-05$ & 0.5117 & 0.60888 & \\
\hline ld_E_1 & 0.327367 & 0.07261 & 4.5086 & $<0.00001$ & $* * *$ \\
\hline alpha(0) & 0.000115444 & 0.000116637 & 0.9898 & 0.32229 & \\
\hline alpha(1) & 0.0556523 & 0.0580353 & 0.9589 & 0.33759 & \\
\hline beta(1) & 0.708942 & 0.254744 & 2.7830 & 0.00539 & $* * *$ \\
\hline
\end{tabular}

\begin{tabular}{|l|c|l|l|c|}
\hline $\begin{array}{l}\text { Arithmetic mean of the } \\
\text { dependent variable }\end{array}$ & -0.001130 & $\begin{array}{l}\text { Standard deviation of dependent } \\
\text { variable }\end{array}$ & 0.024712 \\
\hline Log likelihood & 426.1262 & $\begin{array}{l}\text { Akaike information criterion } \\
\text { (AIC) }\end{array}$ & -818.2523 \\
\hline Bayesian criterion & -764.1620 & & Hannan-Quinn criterion (HQC) & -796.3173 \\
\hline
\end{tabular}


Unconditional error variance model $=0.000490405$

*The variable is statistically significant at the $10 \%$ significance level, $* *$ the variable is statistically significant at the $5 \%$ significance level, $* * *$ the variable is significant at the $1 \%$ significance level.

Source: Authors' own calculations with the use of GRETL program.

Table 2. Augmented Dickey-Fuller test for the uhat process for the 3rd order lag (1L) uhat process, sample size 175

\begin{tabular}{|l|}
\multicolumn{1}{|c|}{ Unit root test for the uhat variable } \\
\hline Null hypothesis: a unit root a $=1$ occurs; process I(1) \\
model: $(1-\mathrm{L}) \mathrm{y}=(\mathrm{a}-1) * \mathrm{y}(-1)+\ldots+\mathrm{e}$ \\
\hline 1st-order auto-correlation of residuals: 0.003 \\
lagged differences: $\mathrm{F}(3.171)=0.852[0.4674]$ \\
estimated value (a-1) is: -0.688655 \\
\hline Test statistic: tau_ct(7) $=-5.85883$ \\
asymptotic p value $=0.007228$ \\
critical value "tau" from Dickey-Fuller tables $=-3.43$ at the $5 \%$ significance level \\
and -3.99 at the $1 \%$ significance level. \\
\hline
\end{tabular}

Source: Authors' own calculations with the use of GRETL.

Analysis of estimation results for equation 9 (Table 1) indicates an economically and statistically significant relationship between changes in M1 money supply in the euro area and USA and the USD/EUR exchange rate changes, changes in the longterm interest rate (a variable lagged by one period) and the increase in the USD/EUR exchange rate, exchange rate changes in the previous period and the increase in the current USD/EUR exchange rate. It is worth noticing that M1 money supply growth in the euro area entails a relatively strong impact on euro depreciation, whereas M1 money supply growth in the USA has an almost equally strong impact on euro appreciation. However, euro depreciation is more strongly affected by changes in the long-term interest rate (a variable lagged by one period). And it is no surprise. As it was mentioned at the beginning of this section - the yield to maturity of long-term (10 year) treasury bonds in the euro area and United States was adopted as a proxy of long-term inflationary expectations. The Treasury bond yield growth is a proxy of expected long-term inflation growth, which results in currency depreciation. The influence of changes in GDP on the exchange rate turned out to be statistically insignificant. The co-integration test (Table 2) points to co-integration of time series.

\section{Conclusions}

The analysis of relationships between changes in monetary policy in the euro area and the nominal USD/EUR exchange rate in the years 1999-2013 lets us formulate the following conclusions: 
a) there is a statistically significant and positive relationship between M1 money supply in the euro area and the nominal USD/EUR exchange rate,

b) there is a statistically significant negative relationship between M1 money supply in the United States and the nominal USD/EUR exchange rate,

c) there is a statistically significant and negative relationship between the treasury bond yield in the United States and the USD/EUR exchange rate.

Recapitulating, the analysis proved a statistically significant and considerable effect of changes in the M1 money supply and long-term treasury bond yields in the United States on changes in the nominal USD/EUR exchange rate over the entire period examined.

\section{References}

Bilski, J. (2006). Międzynarodowy system walutowy. (PWE Warszawa).

Bilson, J.F.O. (1978). The Current Experience with Floating Exchange Rates. An Appraisal of the Monetary Approach. Exchange Rates and Open Economies, Vol. $68 \mathrm{Nr} 2$.

Branson, W.H. (1977). Asset Markets and Relative Prices in Exchange Rate Determination. Socialwissenschaftliche Annalen, Bd. 1, Physica - Verlag, Vien.

Chrabonszczewska, E. and Kalicki, K. (1996). Teoria i polityka kursu walutowego" (SGH, Warszawa).

Dornbusch, R. (1976). Capital Mobility, Flexible Exchange Rates and Macroeconomic Equilibrium. [in:] E. Claassen, P. Salin (eds.), “Recent Issues in International Monetary Economics" (North-Holland, Amsterdam).

Fleming, J.M. (1962). Domestic Financial Policies under Fixed and under Floating Exchange Rates. IMF Stuff Papers, Vol. 9 No 3.

Frenkel, J.A. (1976). A Monetary Approach to the Exchange Rate. Doctrinal Aspects and Empirical Evidence. Scandinavian Journal of Economics No. 78.

Melvin, M. (1992). International Money and Finance. Harper Collins Publisher, New York.

Mundell, R.A. (1963). Capital Mobility and Stabilization Policy under Fixed and under Flexible Exchange Rates. The Canadian Journal of Economics and Political Science, Vol. 29 No 4.

Salvatore, D. (1983). International Economics. Macmillan Publishing Co., London.

Thalassinos, I.E. and Politis, D.E. (2012). The evaluation of the USD currency and the oil prices: A VAR Analysis. European Research Studies Journal, 15(2), 137-146.

Thalassinos, I.E., Th. Stamatopoulos, D.T. and Thalassinos, E.P. (2015). The European Sovereign Debt Crisis and the Role of Credit Swaps. Chapter book in The WSPC Handbook of Futures Markets (eds) W. T. Ziemba and A.G. Malliaris, in memory of Late Milton Miller (Nobel 1990) World Scientific Handbook in Financial Economic Series Vol. 5, Chapter 20.

Thalassinos, I.E., Liapis, K. and Thalassinos, E.J. (2014). The role of the rating companies in the recent financial crisis in the Balkan and black sea area. Chapter book in Economic Crisis in Europe and the Balkans, 79-115, Contributions to Economics, Springer International Publishing, DOI: 10.1007/978-3-319-00494-5-6.

Wdowiński, P. (2010). Modele kursów walutowyc. (Wydawnictwo Uniwersytetu Łódzkiego, Łódź). 